\title{
Happiness: A Journey rather than a Destination in Ayn Rand's The Fountainhead
}

\author{
Sugeetha $\mathrm{K}^{1} \&$ Harini Jayaraman ${ }^{2}$ \\ ${ }^{1}$ PhD Research Scholar, Department of English and Humanities, Amrita School of \\ Engineering, Coimbatore, Amrita Vishwa Vidyapeetham,India. ORCID id: oooo-ooo2- \\ 2668-7440. Email id: k_sugeetha@cb.amrita.edu \\ ${ }^{2}$ Professor, Department of English and Humanities, Amrita School of Engineering, \\ Coimbatore, Amrita Vishwa Vidyapeetham, India. ORCID id: oooo-0oo2-9747-2850. \\ Email id: j_harini@cb.amrita.edu
}

Received November 27, 2017; Revised April 02, 2018; Accepted April 15, 2018; Published May o6, 2018.

\begin{abstract}
The protagonists in the fictional world of Ayn Rand seem to possess the recipe to happiness that matches Hungarian psychologist Csikszentmihalyi's conditions for a "flow experience". This study examines the conditions that lead to the state of "flow" in Ayn Rand's fiction The Fountainhead, with the aim of discovering the criteria that contribute to the leading of a happy life. Although a few critics have discussed the pursuit of happiness in Rand's novels, the objective of this research is to make a difference by attempting to use Csikszentmihalyi's psychological theory to understand Rand's characterization and ascertain the factors that play a major role in the making of a psychologically healthy individual, who as a consequence is frequently in a state of "flow".
\end{abstract}

Keywords: flow, happiness, Mihaly Csikszentmihalyi, The Fountainhead, novelist-philosopher.

\section{Introduction}

Any work of art - a book, a movie, a piece of music, a painting, a sculpture or a play - that inspires a human being to improve the quality of his/her life will usually remain etched in his/her memory forever. Just as human beings pause certain precious moments in the course of their lives and keep replaying those experiences in their minds, it sometimes so happens that a particular scene from a movie, a line spoken by a character or even a piece from a symphony can act as a great motivator, changing the course of many lives. One such scene in Ayn Rand's novel, The Fountainhead, offers a valuable lesson, one that the world at present badly seems to need.

Howard Roark, the protagonist, is an architect, who after immense struggle has received his first commission; he walks through the first building he is working on, giving orders. Mike, his friend who is a construction worker, observes Roark's happiness and comments, "Control yourself, Red. You're open like a book. God, it's indecent to be so happy!" As Roark stands on the cliff and looks down at the country road, a car overfilled with people bound for a picnic drives by. The people in the car seem to be "enjoying a day of their existence; they were shrieking to the sky their release from the work and the burdens of the days behind them; they had worked and carried the burdens in order to reach the goal - and this was the goal." As the car streaks past, it occurs to

(c) AesthetixMS 2018. This Open Access article is published under a Creative Commons Attribution Non-Commercial 4.0 International License (http://creativecommons.org/licenses/by-nc/4.o/), which permits non-commercial re-use, distribution, and reproduction in any medium, provided the original work is properly cited. For citation use the DOI. For commercial re-use, please contact editor@rupkatha.com. 
Roark that there was some "important difference between the consciousness of this day in him and in them" and he reminds himself that he "should try to grasp it." But he forgets as he looks at a truck "panting up the hill, loaded with a glittering mound of cut granite" (Rand, 1992, p. 135).

What this scene suggests is that the majority of mankind takes up a job for survival and considers their occupation a gruesome routine they have to go through, so that they can enjoy the weekend or a holiday or a vacation. People live their life only from weekend to weekend, from holiday to holiday, from vacation to vacation - at other times they simply exist - because the work itself does not interest them. In perfect contrast to the common man who drags himself through what he considers a painful duty, Rand's ideal man has a different perspective to work.

"I have, let's say, sixty years to live. Most of that time will be spent working. I've chosen the work I want to do. If I find no joy in it, then I'm only condemning myself to sixty years of torture. And I can find the joy only if I do my work in the best way possible to me ..." (Rand, 1992, p. 24)

This is the difference that Roark desperately tries to grasp in the above scene: the attitude of people who consider work to be a "necessary evil" or a "punishment in the Garden of Eden" (Smith, 2006, p. 206) and others like him who passionately love their work and take pleasure in doing it efficiently.

In line with Roark's thought process, psychologist, Mihaly Csikszentmihalyi, makes a crucial statement in his scientific study on happiness.

The best moments in our lives are not the passive, receptive, relaxing times . . . The best moments usually occur if a person's body or mind is stretched to its limits in a voluntary effort to accomplish something difficult and worthwhile. (1990, p.3)

Howard Roark experiences many such exhilarating moments throughout the novel - a state of consciousness that Mihaly calls as "flow", where one is completely absorbed in a creative activity. This psychologist defines flow as "a state in which people are so involved in an activity that nothing else seems to matter; the experience is so enjoyable that people will continue to do it even at great cost, for the sheer sake of doing it" (1990, p. 4). For instance, Austen Heller, one of Roark's clients and admirers expresses astonishment at Roark's pleasure in his buildings: “. . . After all, it's only a building. It's not the combination of holy sacrament, Indian torture and sexual ecstasy that you seem to make of it." Roark replies, "Isn't it?" (Rand, 1992, p. 252).

A distinct aspect of Csikszentmihalyi's thesis is that happiness is not an emotion that is dependent on external circumstances but a state of mind that one has to achieve through a great deal of "mental and physical discipline" (Ryckman, 1997, p.453). Considering the fact that it is the desire of every being on earth to be happy, exploring the factors that lead to the achievement of this state of mind in Ayn Rand's work of fiction, The Fountainhead, with psychologist Mihaly's theory as the basis is an interesting venture; moreover, Mihaly himself states that anyone can attain this state of "flow", subject to certain conditions. But before one ventures into an exploration of these conditions, a brief glimpse of Rand's philosophy will definitely help to arrive at a better understanding of the need for an investigation of this nature.

\section{Rand's philosophy}

During a television interview Rand was asked whether she considered herself primarily a novelist or a philosopher, to which she replied that she was both. She further went on to elaborate that 
her main interest in literature and philosophy are to present a concrete image of the ideal human. While studying philosophy, she discovered that she was in disagreement with all the existing philosophies, especially their codes of morality. Hence she had to define her own philosophical system that would result in the character of a human, as he ought to be (Podritske\& Schwartz, 2009, p. 179-18o). It is this urge to present a romanticized vision of a human being that led her to become a novelist-philosopher. Rand's philosophy of "Objectivism" is based on a very strong conviction: "The purpose of morality is to teach you, not to suffer and die, but to enjoy life and live" (Rand, 1992, p. 928).

Craig Biddle in his book Loving Life clarifies the reason why Rand's philosophy is positive and inspiring. In an essay titled "Religion Versus Subjectivism" Biddle explains that generally human beings look up to religion and society for guidance to a happy life, but the common denominator of both is the concept of self-sacrifice. Religion propagates that one must sacrifice oneself for the sake of a higher being and social subjectivism states that one must sacrifice oneself for the sake of the majority. Since it is impossible to find a rational justification for self-sacrifice, and no human being can be truly happy by following either, when Rand propounded a philosophy of self-interest that was perfectly compatible with genuine happiness, it was received with enthusiasm (Podritske \& Schwartz 2004, p. 1-49).

Mihaly's concept of "flow" and Rand's philosophy have three important factors in common: both offer a romanticized vision of a human being, both focus on the individual's selfinterest and both consider happiness as a state of mind that requires moral discipline.

\section{Rand's fiction}

While most philosophers are satisfied with providing abstract answers to questions, being a novelist-philosopher, Rand does not stop with merely presenting the problem but strives to offer a concrete solution through her fiction. In her novels We the Living, Anthem, The Fountainhead and Atlas Shrugged, she uses her fictional characters to express her philosophy of life, therefore when a Randian protagonist speaks he is undoubtedly expressing the author's own opinion. So it is not only Rand's philosophy that has been subjected to discussion, her novels which are bestsellers even today, have also been studied from various perspectives, as elaborated in the ensuing paragraphs.

Tore Boeckmann sees The Fountainhead as a romantic novel not only because the author presents man as a being who possesses volition but also because she tries to actualize man at his highest potential. In yet another essay Boeckmann brings in Aristotle's Poetics to show that fiction gains more importance than history; Rand's Fountainhead is living proof that while history stops with merely presenting facts, fiction projects immense possibilities and shows how things could be. This is probably the reason John Bayer chose to comment on the "spirit of youth" that the novel propagates - when one sees a fictional character not only beginning life with idealism and spirit, but managing to sustain the vision amidst adversity and struggle and achieving success, it demonstrates perseverance and a sense of hope that anything is possible. Shoshana Milgram is so overwhelmed by Rand's characterization of the "ideal man" that in her research article she attempts to discover the true source of inspiration that might have instigated the author to sculpt a man of Roark's stature.

While quite a few critics have examined the plot, characterization and style of Rand's novels, it is the theme that has been predominantly the subject of discussion. Onkar Ghate discusses the battle between good and evil in Rand's world and stresses that although evil is 
basically impotent, it is important to study the nature of evil in order to overcome it and succeed. Another essay by Tara Smith makes a crucial finding: Howard Roark is the only character in The Fountainhead who is serene and happy throughout. With respect to his relationships with people, at work, or with respect to handling critical situations, he seems to possess a certain attitude that makes him immune to pain and open to joy. Dr. Nathaniel Branden, an ardent fan of Ayn Rand, a writer and thinker, in his essay "Reflections on Happiness" seems to express similar views. Branden is confident that the attitude a person has determines how happy he is, rather than the external events of his life; what really needs to be examined is how a worthy person processes his experiences, so much so that he is happy even amidst adversities (n.p.). While this attitude applies to all spheres of a person's life, the researcher proposes to focus specifically on the professional sphere; since a person's productivity at work affects not just the organization he works for, but the society, the country and the world as a whole.

Amongst the research essays by various critics, Tara Smith's character analysis and Nathaniel Branden's article on "Happiness" are the closest to the theme that the researcher has chosen for study. But Branden stops with observing that happiness is a state of mind or an attitude that has to be developed, and Tara Smith merely compares and contrasts Roark with the other characters in the novel. While Branden does not use Rand's fiction as a case study to lend validity to his concept, both refrain from using any psychological theories to explore what it takes to evolve into a "happy" person. The research scholar desires to make a difference by attempting to use Csikszentmihalyi's psychological theory to understand Rand's characterization and thereby lend more credibility to her ideas.

Ayn Rand in her novel, The Fountainhead, chooses to tell the success story of an architect, Howard Roark, who, in spite of the challenges that threaten his progress at work, is in a constant state of euphoria. Rand shows how anyone can acquire this feat, through a rational philosophy that is logically compatible with the criteria put forth by Mihaly to experience the state of "flow". The methodology used in this paper is an examination of the conditions laid by Mihaly to achieve the state of "flow" with respect to Rand's work of fiction, The Fountainhead. The first condition suggested by Mihaly is the degree of a person's independence in making his career choice.

\section{a) Making Independent Choices}

Every human endeavours to be successful in his career but according to Mihaly the effort begins right from childhood, from the time a person starts making choices and setting goals in life. In Mihaly's opinion, clarity in goal-setting is an essential quality of people who experience the highest levels of flow (1990, p. 88-89); in The Fountainhead a conversation between Howard Roark and architect Henry Cameron during Roark's first job interview reveals this quality.

"When did you decide to become an architect?"

"When I was ten years old."

... Why did you decide to be an architect?"

"I didn't know it then. But it's because I've never believed in God."

"Come on, talk sense."

"Because I love this earth. That's all I love. I don't like the shape of things on this earth. I want to change them." (Rand, 1992, p.51) 
It is only natural then that a person who chooses the field he so passionately loves derives immense joy and satisfaction despite the challenges and threats. Interestingly, another character in the novel, Peter Keating, who had wanted to be an artist, allows his mother to choose a better field for him in which to exercise his talent for drawing. "Architecture," she had said, "is such a respectable profession. Besides, you meet the best people in it." Keating chooses his profession because his mother pushes him into it, and he believes that architects always made "brilliant careers" (Rand, 1992, p. 31). Unlike Roark, Keating is always afraid to take responsibility for his choices and usually prefers others making decisions for him. After his graduation he is confused whether to accept a scholarship for higher studies or go to work and consults Roark, his junior at college.

"It's about my scholarship. The Paris prize I got."

"Yes?"

"It's for four years. But, on the other hand, Guy Francon offered me a job with him some time ago. Today he said it's still open. And I don't know which to take."

Roark looked at him; Roark's fingers moved in slow rotation, beating against the steps.

"If you want my advice, Peter," he said at last, "you've made a mistake already. By asking me. By asking anyone. Never ask people. Not about your work. Don't you know what you want? How can you stand it, not to know?"

"You see, that's what I admire about you, Howard. You always know." (Rand, 1992, p. 33)

While Roark finds it inconceivable that an individual needs other people to decide about his work, for Peter it is quite normal to consult others because the motivating factor in his life is not the work but the people whom he wishes to impress. Rand portrays the consequences of choices people make without independent thinking by tracing the career of Peter Keating which begins with flourish but ends in failure. Csikszentmihalyi clarifies that this is the reason most people end up with "boredom, depression and anxiety" in their jobs and recommends that people must learn to become more "independent of their social environment" implying that to find enjoyment and purpose in life one must exercise one's individuality and not become a mere puppet of society (Ryckman, 1997, p. 454). In other words, the motive force behind one's career choice plays a major role in deciding the person's degree of happiness.

\section{b) The Motive Force}

In her novel, Rand uses the literary technique of juxtaposing the careers of two architects with contrasting personalities to convey an important message: a person whose motive force is his "work" can live in a constant state of "flow" and celebrate existence but a neurotic whose driving force is "people" can only lead a miserable existence. Howard Roark, the happy individualist in The Fountainhead is free of societal constraints throughout the course of his career and in perfect control of his life. The novel begins with Roark's expulsion from Stanton University for his radical ideas; an encounter with the Dean before he leaves Stanton and begins his career speaks volumes about his work philosophy. The conversation begins with the Dean advising Roark not to be an idealist.

"There's the practical side of an architect's career to think about. An architect is not an end in himself. He is only a small part of a great social whole. Co-operation is the key 
word to our modern world and to the profession of architecture in particular. Have you thought of your potential clients?"

"Yes," said Roark.

"The Client," said the Dean. "The Client. Think of that above all. He's the one to live in the house you build. Your only purpose is to serve him. You must aspire to give the proper artistic expression to his wishes. Isn't that all one can say on the subject?"

Well, I could say that I must aspire to build for my client the most comfortable, the most logical, the most beautiful house that can be built. I could say that I must try to sell him the best I have and also teach him to know the best. I could say it, but I won't. Because I don't intend to build in order to serve or help anyone. I don't intend to build in order to have clients. I intend to have clients in order to build." (Rand, 1992, p. 26)

Roark's answer clearly reveals that his intention is not altruistic; he aims for personal achievement, not to serve society. Roark's characterization celebrates people who are interested in improving the quality of their work and as a consequence make the world a better place through their creative work. Austen Heller, one of Roark's clients, who admires and understands Roark's work, expresses it clearly, "Your house is made by its own needs. The others are made by the need to impress. The determining motive of your house is in the house. The determining motive of the others is in the audience" (Rand, 1992, p. 136). Rand brands individualists like Roark as "first-handers" and contrasts their approach with "second-handers" like Peter Keating whose prime concern and motive are other people. Keating has no wish to build but wants "to be admired as a builder", he does not wish to be great "but to be thought great" (Rand, 1992, p. 605).

When Keating begins a project he hates "every girder of that building" even "before it was born"; when he enters a competition, instead of focusing on the drawing at hand he worries more about who might solve the problem better and win the competition and be declared publicly superior to him (Rand, 1992, p. 172). Therefore he is plagued by doubts about the quality of his work and feelings of jealousy and this affects his performance. This again only proves to reiterate another important view of Mihaly's; concentrating on living the present moment to the fullest is the basic criteria to experience the state of "flow" (Ryckman, 1997, p. 454).

\section{c) Living the Present}

Peter Keating is ambitious to make money, gain power, and raise his status in society, since he lives in the future and concentrates more on the results that he can reap from his work rather than the work itself, he can never hope to match Roark's accomplishment. Mihaly goes to the extent of stating that "whether a job provides enjoyment or not" does not depend on the external working conditions but on the "person's approach to it" (1990, p. 161). Even a commonplace job can become exciting if the individual shows interest and involvement. In The Fountainhead, Mike, Roark's friend, on the surface appears to be doing a monotonous job that involves only physical labour; he is a construction worker. What seems to be a boring manual labour to others, to Mike is a skill that he has acquired and mastered. He takes pride in his expertise, worships his job and takes pleasure in doing it efficiently. "His view of the world was simple: there were the able and there were the incompetent; he was not concerned with' the latter" (Rand, 1992, p. 93). Similarly when Roark refuses to compromise his ideals and is compelled to work as a manual labourer in a granite quarry, he focuses on the work at hand and even under those adverse conditions translates the threat into a challenge. 
He liked the work. He felt at times as if it were a match of wrestling between his muscles and the granite. He was very tired at night. He liked the emptiness of his body's exhaustion. (Rand, 1992, p.201)

Even in such a barren environment, when he has no clients, Roark is a happy man as he has a long-term goal. He makes use of the opportunity to study new material, learn a new skill and save money to start his own office in the future. Since his mind is filled with innovative designs which can add value to the world and plans to build new structures, minor hindrances do not matter. Roark lives the moment by doing the work at hand with superlative efficiency, the nature of the work does not really matter to him. Csikszentmihalyi's research concludes that people (like Roark) who have cultivated this inner tranquility even when external circumstances are not so conducive are psychologically healthy and more inclined to experiencing the state of "flow. An important consequence of the concept of "flow", is the confirmation of Aristotle's view that "happiness cannot be identified with pleasure" (1990, p.129).

\section{d) Distinguishing Happiness from Pleasure}

Leonard Peikoff, a follower of Ayn Rand's “Objectivist Philosophy” reasons that Rand's view of happiness differs from two common approaches: one regards happiness as the equivalent of pleasure and the other considers pleasure as "animalistic, unspiritual, immoral" (1991, p. 341-342). Randian thought considers that happiness and pleasure are not the same, as a matter of fact, happiness is perfectly moral and a state of mind that is not easy to achieve. In the scene that was described in the beginning of this research paper, the people going on a picnic experience a temporary state of pleasure but in a passive state, that cannot be identified as "flow". Roark also derives pleasure from his work but in an active state that is completely under his control, it is this intense emotion that Aristotle and Rand call "happiness".

There is a vital difference between the quality of pleasure experienced by people when they wait for the end of a workaday to drown their conscious in liquor or television or a movie and the pleasure experienced by a person who has a creative goal and takes pride in the productive use of his mind. In Nathaniel Branden's words, "his enjoyment is fed by his unceasing concern to grow in knowledge and ability - to think, to achieve, to move forward, to meet new challenges and overcome them ..." (1964, p. 73). It is only natural then that an individual who is in such active control of his conscious, understands the meaning of existence; Rand offers a simple solution to a human being's quest for the meaning of life through a discussion between Roark and Gail Wynand, the newspaper editor in The Fountainhead.

"Look, Gail." Roark got up, reached out, tore a thick branch off a tree, held it in both hands, one fist closed at each end; then, his wrists and knuckles tensed against the resistance, he bent the branch slowly into an arc. "Now I can make what I want of it: a bow, a spear, a cane, a railing. That's the meaning of life."

"Your strength?"

"Your work." He tossed the branch aside. "The material the earth offers you and what you make of it.... (1992, p. 551)

Rand's greatest achievement as a novelist was to portray through her heroes, how the passionate commitment to one's work, can make each moment worthwhile, give him a unique identity and make a valuable contribution to his happiness. When each individual is able to tap his complete potential, he makes a valuable contribution to society and his productivity leads to 
the development of the country and naturally benefits the whole world. Hence this is an issue that not only affects an individual's self-esteem but the fate of entire mankind.

So an important question that arises is that if "flow" is a state achieved by a minority willing to exert the effort, what is the role played by the majority who has never enjoyed a similar experience. Rand's answer is that such people who are incapable of personal achievement not only denounce achievers but spread the concept of social service.

\section{e) Personal Achievement and Social Service}

Historical evidences prove that most countries that have not made much progress are those where the creative men have not been appreciated. Numerous instances in history prove that great thinkers have been scorned, ridiculed and rejected by society. Andrew Bernstein quotes Galileo and Socrates as examples of independent thinkers who faced severe opposition, yet they are the ones who have helped the world evolve into a better place (2008, p. 61).

Rand's logic is that a lot of people may be born with talent but are unwilling to set goals for themselves since it requires tremendous self-discipline; they wish to be appreciated but are not ready to live by the standards that success demands. So their natural instinct is to destroy any individual who realizes his capacity for achievement and lives up to his highest and best potential. Ayn Rand's reasoning is proved through the character of Ellsworth Toohey, a newspaperman who attempts to destroy Roark through his newspaper column. Men like Roark are a reproach to Toohey, so he seldom allows a person who approaches him for counsel to take up the work he loves, for he is aware that it is the only source of joy and independence, a state that he himself can never reach. He makes apt use of his oratory skills when the occasion arises and thereby kills their desire to live and achieve.

No. I wouldn't go in for law if I were you. You're much too tense and passionate about it. A hysterical devotion to one's career does not make for happiness or success. It is wiser to select a profession about which you can be calm, sane and matter-of-fact. Yes, even if you hate it. It makes for down-to-earthness. (Rand, 1992, p. 301)

He argues that the only chance of redemption is to choose the kind of work which paves the way for service to mankind and not for egoistical satisfaction. Novelist-philosopher Ayn Rand, who exalts personal achievement in her fiction and non-fiction works, strongly advocates that an individual is what he does; only those who cannot do anything worthwhile with their lives exalt social service. Ironically society has gained more through the services of worthy men who took pride in their personal achievements than those who claim to have sacrificed their lives for the welfare of society. Hence Rand communicates that the key to a person's happiness should always be in his possession, the moment he hands over the control to other people, he becomes dependent on them.

\section{Conclusion}

In a radio show Rand was asked a clichéd question "What is the purpose of life?" She replied that "there is no such thing as 'the purpose of life,' because life is an end in itself. Life is the purpose of life. And nature has given us a very good way of knowing whether we are spending our lives properly or not - namely, whether we are happy or not" (Podritske\& Schwartz, 2009, p. 246-247). The novelist-philosopher's message is that instead of lamenting that they do not understand the 
meaning of life and seeking some higher purpose or yearning for an afterlife which may not even exist, human beings must realize that happiness is not a destination that one strives to achieve but a journey that can make life exciting and adventurous.

Since the major part of the conscious hours of every person's life would be spent on the work that he has chosen for his survival, it is only sensible that he chooses a vocation that he not only loves but also has an aptitude for. Once he makes the choice, he can be truly happy only if he takes complete responsibility for his actions and does his job to the best of his ability. Failing to do this will not only make him miserable, but also lead to a valuable loss of human talent and resources, which if properly utilized might have made a major contribution to the betterment of humanity.

The very intention behind choosing Csikszentmihalyi's theory in this article was that this psychologist promotes the belief that people who often experience "flow" are more likely to be psychologically healthy individuals. Living in an age where mental health seems to be in a state of deterioration, where an increasing number of people seem to be plagued by depression, suicidal tendencies and behavioural disorders, it becomes all the more important to find ways and means to prevent psychological diseases. The best method to prevent any such pathology would be to create an environment that can only result in positive emotions; the fictional world of Rand thus proved to be an apt setting for a self-contained hero like Howard Roark. So the "flow" theory that falls under the category of positive psychology can play a predominant role in inducing an ambience that is conducive to the mental health of a country. Considering the fact that there are "romantic" authors such as Rand who strive to project human beings as they ought to be and "realistic" writers who present people in their depraved state, the "flow" theory can be applied to both kinds of fiction to paint a clear picture of what makes an individual neurotic and how the person can become self-sufficient by adopting the guidelines suggested by psychologist Csikszentmihalyi.

\section{References}

Bayer, J. H. (2007). The Fountainhead and the Spirit of Youth. In R. Mayhew (Ed.), Mayhew Essays on The Fountainhead (pp.227-242). Lanham: Lexington.

Bernstein, A. (2008). Objectivism In One Lesson: An Introduction to the Philosophy of Ayn Rand. Lanham: Hamilton.

Biddle, C.(2004). Loving Life: The Morality of Self-Interest and the facts that Support It. Richmond: Glen Allen Press.

Boeckmann, T. (2007). The Fountainhead as a Romantic Novel. In R. Mayhew (Ed.), Mayhew Essays onThe Fountainhead (pp. 119-154). Lanham: Lexington.

Boeckmann, T. (2007). What Might Be and Ought to Be: Aristotle's Poetics and The Fountainhead. In R. Mayhew (Ed.), Mayhew Essays onThe Fountainhead (pp. 155-176). Lanham: Lexington.

Branden, N. (1964). The Psychology of Pleasure. In A. Rand The Virtue of Selfishness (pp. 71-78). New York: Signet.

Branden, N. (2013). Reflections on Happiness. Retrieved from

$<$ http://www.nathanielbranden.com/reflection-on-happiness $>$.

Csikszentmihalyi, M. (1990). Flow: The Psychology of Optimal Experience. New York: Harper \& Row. 
Ghate, O. (2007). The Basic Motivation of the Creators and Masses in The Fountainhead. In R. Mayhew (Ed.), Mayhew Essays onThe Fountainhead (pp. 243-284). Lanham: Lexington.

Milgram, S. (2007). Three Inspirations for the Ideal Man: Cyrus Paltons, Enjolras, and Cyrano de Bergerac. In R. Mayhew (Ed.), Mayhew Essays onThe Fountainhead (pp. 177-200). Lanham: Lexington.

Peikoff, L. (1991). Objectivism: The Philosophy of Ayn Rand. New York: Meridian.

Podritske, M \& Schwartz, P. (Eds.), (2009). Objectively Speaking: Ayn Rand Interviewed. Lanham: Lexington Books.

Rand, A. (1992). The Fountainhead. New York: Signet.

Rand, A. (1992). Atlas Shrugged. New York: Signet.

Ryckman, M. R. (Ed.). (1997). Theories of Personality. CA: Brooks/Cole Publishing Company.

Smith, T. (2006). Ayn Rand's Normative Ethics. New York: Cambridge University Press.

Smith, T. (2007). Unborrowed Vision: Independence and Egoism in The Fountainhead. In R. Mayhew (Ed.), Mayhew Essays on The Fountainhead (pp. 285-304). Lanham: Lexington. 